\title{
2012 outbreak of acute haemorrhagic conjunctivitis in Indian Ocean Islands: identification of Coxsackievirus A24 in a returned traveller
}

C Aubry' ${ }^{1}$ P Gautret ${ }^{1}$, A Nougairede ${ }^{2}$, A S Dussouil ${ }^{1}$, E Botelho-Nevers ${ }^{1}$, C Zandotti $^{1}$, X De Lamballerie ${ }^{2}$, P Brouqui $^{1}$,

P Parola (philippe.parola@univ-amu.fr) ${ }^{1}$

1. University Hospital Institute for Infectious and Tropical Diseases, EuroTravNet Coordination Center, Assistance PubliqueHôpitaux de Marseille (AP-HM), Aix-Marseille University, Marseille, France

2. Virology laboratory, Timone Hospital, Hospital Institute for Infectious and Tropical Diseases, Assistance Publique-Hôpitaux de Marseille (AP-HM), Aix-Marseille University, Marseille France

In May 2012, a Coxsackievirus A24 haemorrhagic conjunctivitis was diagnosed in Marseille, France, in a traveller returning from the Comoros Islands. This case allowed identification of the cause of an ongoing outbreak of haemorrhagic conjunctivitis in Indian Ocean Islands, illustrating that returning travellers may serve as sentinels for infectious diseases outbreaks in tropical areas where laboratory investigation is limited.

\section{Background}

An outbreak of acute haemorrhagic conjunctivitis occurred from February to May 2012 in Mayotte, a French island in the South-West Indian Ocean, where it accounted for $15 \%$ to $45 \%$ of consultations in primary care structures $[1,2]$. Over 1,000 cases had been reported, based on clinical criteria by the end of March $2012[1,2]$. The outbreak had now spread to the Union of the Comoros*, but the current number of cases is unknown. The disease, called Matso-matso by the local population (Matso meaning 'the eyes' in the local language) is recognised there to be highly contagious, and the intensity of the outbreak is illustrated by the number of people wearing black sun glasses on the streets [3]. Acute haemorrhagic conjunctivitis outbreaks have also been described in local newspapers in Madagascar [4] and Mauritius [5]. The aetiology of this outbreak was not known by 25 May 2012.

\section{Case description}

We report here a case of haemorrhagic conjunctivitis in a traveller returning from the Union of the Comoros* to Marseille, France. The patient was in his 20s, born in France, and presented on 14 May 2012 with a diagnosis of lower limb erysipelas secondary to super-infection of arthropod bites, and a bilateral haemorrhagic purulent conjunctivitis that started four days earlier. He had been staying from 15 April to 14 May 2012 in the south of the island of Ngazidja (Grande Comore) with the purpose of visiting friends and relatives. He reported that five close members of his family, as well as other inhabitants of the same village, were affected by bilateral conjunctivitis during his stay. In our hospital, the erysipela was successfully treated by antibiotic therapy (amoxicillin/clavulanic acid, $3 \mathrm{~g}$ per day) and the patient was discharged on 18 May, with improvement of conjunctivitis symptoms using nonantibiotic eye lubricant drops. No secondary conjuntivitis cases were observed among his relatives in France.

\section{Virological analysis}

Conjunctival swabs were sent to the laboratory of virology at the Marseille University Hospital. A real-time PCR assay detecting human enteroviruses was performed as described previously [6] and enterovirus RNA was detected (cycle threshold: $n=34$ ). Virus isolation was attempted using Vero, BGM and MA104 cells and is still in progress, and molecular typing (nested RT-PCR) was performed as previously described [7], using the nucleic acid extract of the initial sample. The nested PCR allowed amplification of a $327 \mathrm{bp}$ partial sequence of the VP1 gene. Direct sequencing of the amplicon provided the definitive identification of coxsackievirus A24 variant (CV-A24v) via BLAST analysis [8]. The partial sequence obtained was aligned for comparison with other homologous CV-A24V virus sequences using Clustal X [9]. Phylogenetic analysis was performed using neighbour-joining method (Jukes-Cantor algorithm) in MEGA 5.0 software [10] and confirmed that the virus detected is CV-A24V (Figure). The sequence has been deposited in GenBank under accession number JX196594**.

\section{Discussion}

Coxsackievirus A24, enterovirus 70 and some adenovirus serotypes are the main pathogens responsible for acute haemorrhagic conjunctivitis, which occurs as 
Phylogenetic analysis of coxsackievirus A24v patient isolate, based on a partial VP1 nucleotide sequence, Marseille, May 2012

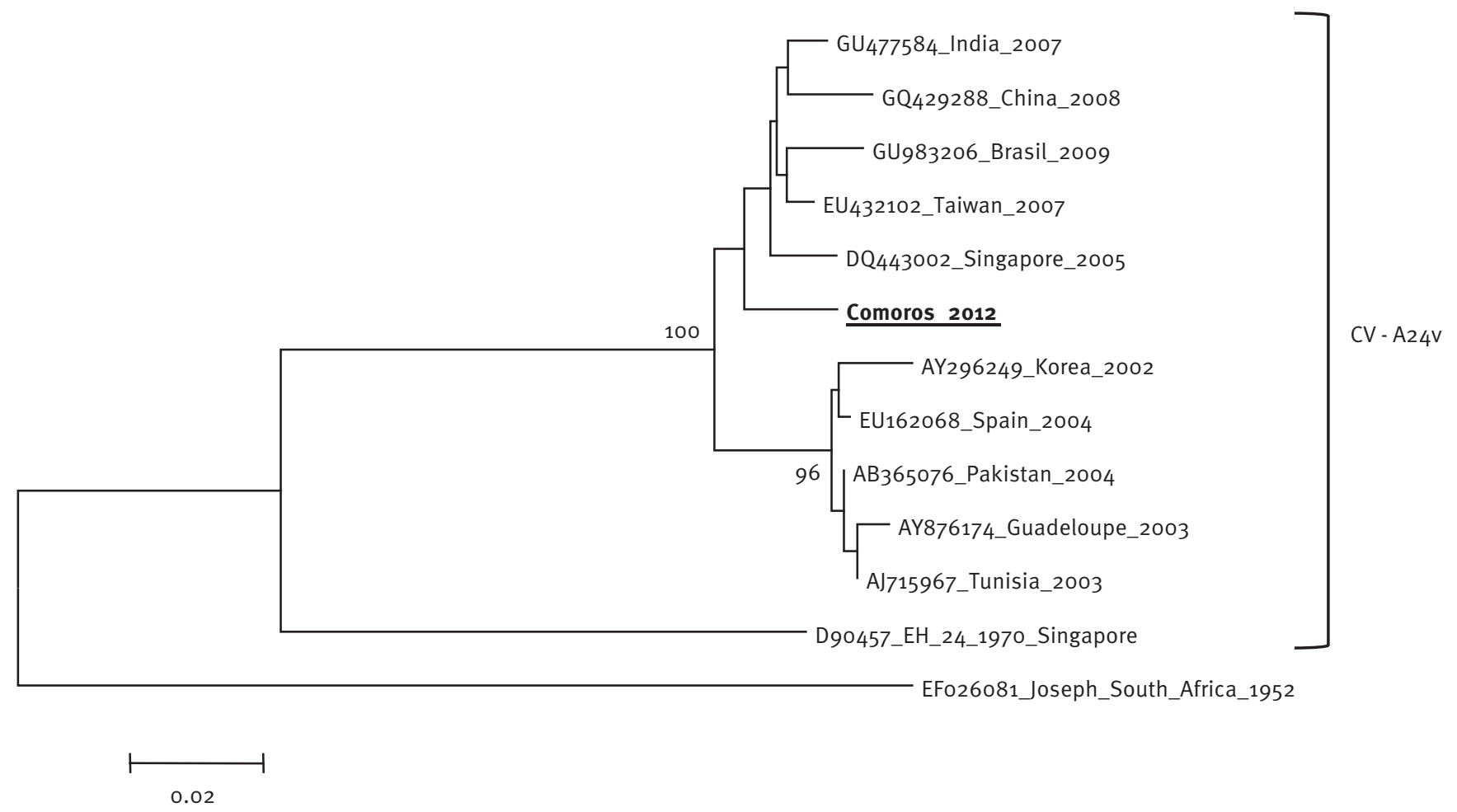

The phylogenetic tree was based on nucleotide sequences in the VP1 gene. It was constructed using the neighbour-joining method. Bootstrap values $>70 \%$ are indicated (1,000 replicates). The virus called Comoros_2012 is that detected in this study (complete sequence available on request)

seasonal outbreaks, particularly in tropical and subtropical areas [11]. Epidemics were first described in Ghana in 1969 [12], and CV-A24V was first isolated during an epidemic in Singapore in 1970 [13]. In the past four decades, CV-A24V was recognised as the major pathogen responsible for acute haemorrhagic conjunctivitis epidemics [14-16] and has recently been responsible for outbreaks in Brazil, China, Cuba, Sudan and Uganda [17-20]. Human-to-human direct transmission is usually through lachrymal secretions or respiratory contamination [21]. Indirect transmission through contaminated ophthalmological device or swimming pool waters has also been described [22].

In Marseille, the population originating from Comoros has been estimated at 50,000 to 70,000 inhabitants, although the precise number is difficult to assess [23]. Therefore, Marseille University Hospital Insitute for Infectious and Tropical Diseases can be used as a sentinel to document outbreaks occurring in south-west Indian Ocean Islands [24].

This new outbreak of acute haemorrhagic conjunctivitis in Comoros, but also in Madagascar and Mauritius raises concerns of local spread in Indian Oceans
Islands, as well as of new cases imported from there to Europe. The possibility of an outbreak in Europe and specifically France, given the high contagiousness of the disease cannot be excluded. Strict adherence to hygiene rules is essential for the control of the epidemics. No member of our hospital team has been contaminated in the context of the case described here.

We demonstrate one more time that travellers may act as sentinels to document infectious disease outbreaks in tropical areas where laboratory tools are limited.

* Authors' correction:

The name of Comoros was corrected on 13 June 2012 at the request of the authors.

\section{** Addendum}

The sequence has been deposited in GenBank under accession number JX196594 [added on 2 July 2012]. 


\section{References}

1. Institut de Veille Sanitaire. Epidémie de conjonctivite à Mayotte. [Conjunctivitis epidemic in Mayotte]. Point épidémiologique no. 15, CIRE Océan indien; 22 Mar 2012. French. Available from: http://www.ars.ocean-indien.sante.fr/ fileadmin/OceanIndien/Internet/Veille_et_securite sanitaire/ Gestion_de_crise_sanitaire/CIRE/Dossiers_thematiques/ Conjonctivite/220312_15_conjonctivite_MAY.pdf

2. Institut de Veille Sanitaire. Epidemie de conjonctivites à Mayotte. [Conjunctivitis epidemic in Mayotte]. Point épidémiologique no. 18, CIRE Océan indien; 6 Apr 2012. French. Available from: http://www.invs.sante.fr/content/ download/34667/170451/version/7/file/pe_conjonctivites mayotte_060412.pdf

3. Attention, “Matso-matso" est de retour à Ndzuwani! [Attention, "Matso-matso" is back in Ndzuwani!]. Al-watwan no. 1942; 25 Apr 2012. French. Available from: http://www.alwatwan.net/ pdf/25042012.pdf

4. Andrianarisoa V. La conjonctivite sévit à Mahajanga.

[Conjunctivitis is rife in Mahajanga]. L'express de Madagascar no.5235; 30 May 2012. French. Availabale from: http:// www.lexpressmada.com/epidemie-madagascar/33417-laconjonctivite-sevit-a-mahajanga.html

5. Conjunctivitis: highly contagious. Le défi Mediagroup Mauritius News Information Portal. 22 Mar 2012. Available from: http://www.defimedia.info/news-sunday/health/ item/8525-conjunctivitis--highly-contagious.html

6. Tan CY, Ninove L, Gaudart J, Nougairede A, Zandotti C, Thirion-Perrier $L$, et al. A retrospective overview of enterovirus infection diagnosis and molecular epidemiology in the public hospitals of Marseille, France (1985-2005). PLoS One. 2011;6(3): 18022.

7. Nix WA, Oberste MS, Pallansch MA. Sensitive, seminested PCR amplification of VP1 sequences for direct identification of all enterovirus serotypes from original clinical specimens. J Clin Microbiol. 2006;44(8):2698-704.

8. Altschul SF, Gish W, Miller W, Myers EW, Lipman DJ. Basic local alignment search tool. J Mol Biol. 1990;215(3):403-10.

9. Larkin MA, Blackshields G, Brown NP, Chenna R, McGettigan $\mathrm{PA}, \mathrm{McWilliam} \mathrm{H}$, et al. Clustal $\mathrm{W}$ and Clustal $\mathrm{X}$ version 2.0. Bioinformatics. 2007;23(21):2947-8.

10. Tamura K, Peterson D, Peterson N, Stecher G, Nei M, Kumar S. MEGA5: molecular evolutionary genetics analysis using maximum likelihood, evolutionary distance, and maximum parsimony methods. Mol Biol Evol. 2011;28(10):2731-9.

11. Chang $\mathrm{CH}$, Sheu MM, Lin $\mathrm{KH}$, Chen CW. Hemorrhagic viral keratoconjunctivitis in Taiwan caused by adenovirus types 19 and 37: applicability of polymerase chain reaction-restriction fragment length polymorphism in detecting adenovirus genotypes. Cornea. 2001;20(3):295-300.

12. Chatteriee S, Quarcoopome CO, Apenteng A. Unusual type of epidemic conjunctivitis in Ghana. Br J Ophthalmol. 1970;54(9):628-30.

13. Lim KH, Yin-Murphy M. An epidemic of conjunctivitis in Singapore in 1970. Singapore Med J. 1971;12(5):247-9.

14. Cabrerizo M, Echevarria JE, Otero A, Lucas P, Trallero G. Molecular characterization of a coxsackievirus A24 variant that caused an outbreak of acute haemorrhagic conjunctivitis in Spain, 2004. J Clin Virol. 2008;43(3):323-7.

15. Triki H, Rezig D, Bahri O, Ben Ayed N, Ben Yahia A, Sadraou A, et al. Molecular characterisation of a coxsackievirus A24 that caused an outbreak of acute haemorrhagic conjunctivitis, Tunisia 2003. Clin Microbiol Infect. 2007;13(2):176-82.

16. Wu D, Ke CW, Mo YL, Sun LM, Li H, Chen QX, et al. Multiple outbreaks of acute hemorrhagic conjunctivitis due to a variant of coxsackievirus A24: Guangdong, China, 2007. J Med Virol. 2008;80(10):1762-8.

17. De W, Huanying Z, Hui L, Corina M, Xue G, Leng L, et al. Phylogenetic and molecular characterization of coxsackievirus A24 variant isolates from a 2010 acute hemorrhagic conjunctivitis outbreak in Guangdong, China. Virol J. 2012;9:41.

18. Fonseca MC, Sarmiento L, Resik S, Pereda N, Rodríguez H, Kourí V, et al. Isolation of Coxsackievirus A24 variant from patients with hemorrhagic conjunctivitis in Cuba, 2008-2009. J Clin Virol. 2012;53(1):77-81.

19. Tavares FN, Campos Rde M, Burlandy FM, Fontella R, de Melo MM, da Costa EV, et al. Molecular characterization and phylogenetic study of coxsackievirus A24v causing outbreaks of acute hemorrhagic conjunctivitis (AHC) in Brazil. PLoS One. 2011;6(8):e23206.

20. Centers for Disease Control and Prevention (CDC). Notes from the field: acute hemorrhagic conjunctivitis outbreaks caused by coxsackievirus A24v Uganda and southern Sudan, 2010. MMWR Morb Mortal Wkly Rep. 2010;59(32):1024.
21. Yin-Murphy M, Goh KT, Phoon MC, Yao J, Baharuddin-Ishak. A recent epidemic of acute hemorrhagic conjunctivitis. Am J Ophthalmol. 1993;116(2):212-7.

22. Chomel JJ, Gaudin OG, Nejmi S, Sohier R. Conjonctivite aiguë hémorragique épidémique due à un nouvel enterovirus. [Acute epidemic haemorrhagic conjunctivitis due to an enterovirus]. Nouv Presse Med. 1973;2(26):1781-3. French.

23. Parola P, Pradines B, Simon F, Carlotti MP, Minodier P, Ranjeva $M P$, et al. Antimalarial drug susceptibility and point mutations associated with drug resistance in 248 Plasmodium falciparum isolates imported from Comoros to Marseille, France in 20042006. Am J Trop Med Hyg. 2007;77(3):431-7.

24. Parola P, de Lamballerie X, Jourdan J, Rovery C, Vaillant V, Minodier $\mathrm{P}$, et al. Novel chikungunya virus variant in travelers returning from Indian Ocean islands. Emerg Infect Dis. 2006;12(10):1493-9. 